\title{
Comparing Individual Attitudes about EU Membership in Turkey and in Post-Communist Central and Eastern European Countries
}

Çiğdem Kentmen

Izmir University of Economics

\begin{abstract}
This article examines whether theories previously developed to explain variations in individual attitudes toward European Union (EU) membership in post-communist Central and Eastern European countries (CEECS) also explain attitudes in Turkey. In CEECs, attitudes reflect whether individuals feel they win or lose in economic and democratic transitions. Although Turkey did not experience a transition from communism to liberal democracy, its political and economic spheres have nevertheless changed to meet EU membership conditions. Using 2002.2 and 2003.2 Eurobarometers, I found that, while satisfaction with economic circumstances significantly increased pro-EU attitudes, satisfaction with the democratic system did not increase pro-EU attitudes in Turkey and many CEECs.
\end{abstract}

Keywords: Public opinion, EU membership, Turkey, Central and Eastern Europe.

\section{Introduction}

The existing literature on public support for the European Union (EU) has generally focused on two groups of countries. The first group includes Western European member states. For example, the Norwegian referenda in 1972 and 1994, in which the electorate rejected Norway's accession, and the Danish 1992 referendum, in which the electorate voted against the Maastricht Treaty, prompted scholarly interest in the determinants of support for integration with Western Europe. ${ }^{1}$ The second group includes Central and Eastern European countries (CEECs) ${ }^{2}$ where public approval for EU membership was required to complete the accession process. This group provides an interesting case because, unlike the Western European member states, these countries were experiencing a transition from an authoritarian communist system to a democracy and market economy. These changes had an important influence on individual attitudes towards EU membership. The CEECs also provided an opportunity for public opinion scholars to test whether they could generalize theories explaining variation in individual opinion in Western European countries to post-communist Europe. $^{3}$

Çiğdem Kentmen, Asst. Prof. Dr., Department of International Relations and European Union, Izmir University of Economics. E-mail: cigdem.kentmen@ieu.edu.tr.

See Adam P. Brinegar and Seth K. Jolly, "Location, Location, Location: National Contextual Factors and Public Support for European Integration," European Union Politics 6 (2005); Richard Eichenberg and Russell J. Dalton, "Europeans and the European Community: The Dynamics of Public Support for European Integration," International Organization 47 (1993); Mark Franklin, Michael Marsh and Lauren McLaren, "Uncorking the Bottle? Popular Opposition to European Unification in the Wake of the Maastricht Treaty," Journal of Common Market Studies 32 (1994).

2 This group of countries includes Bulgaria, the Czech Republic, Estonia, Latvia, Lithuania, Hungary, Poland, Romania, Slovakia and Slovenia.

3 See Rachel A. Cichowski, "Western Dreams, Eastern Realities: Support for the European Union in Central and Eastern 
Although Turkey has been a candidate country since 1999, the existing literature has generally failed to identify the dynamics of citizen support for Turkey's accession to the EU. There are few studies providing empirical evidence on public opinion on the EU in Turkey, and none of these studies compares whether the factors explaining attitudes in Turkey are the same as in other candidate countries. ${ }^{4}$ This study is the first to compare the determinants of EU attitudes in Turkey and the CEECs.

The study tests two types of theories within the context of Turkey and the CEECs: utilitarian theories and democratic support theory. Utilitarian theories argue that citizens who benefited from an economic transition from a communist system to a liberal economy would support their country's EU membership. ${ }^{5}$ The underlying assumption is that those individuals would hold the EU responsible for beneficial economic changes. Democratic support theory applies a similar logic. Those who are satisfied with how democracy works after the collapse of the communist system would support EU succession for two reasons: first, EU membership conditions help build a democratic system, and second, EU membership guarantees that these countries will never return to an authoritarian system. Thus, citizens would again hold the EU responsible for how democracy works in their country. ${ }^{6}$

The analyses presented here reveal that attitudes in Turkey do not differ substantially from those in the CEECs. Beneficiaries of economic changes support EU membership in all countries concerned. More specifically, individuals' evaluations of the EU's impact on national economies have the largest impact on support for EU membership across all countries: those who are content with their current personal economic situation and future prospects are also likely to support EU accession. In contrast, in Turkey, Hungary, Poland and Romania there was no significant effect of satisfaction with democracy on individual attitudes toward EU membership. In other words, the argument that winning from democratization leads to proEU attitudes is not supported in these CEECs or in Turkey.

\section{Winners and Losers in Economic Reforms}

Public opinion research has identified utilitarian calculations as an important factor in explaining individual attitudes toward EU membership. Existing research suggests that individuals evaluate their country's accession to the EU on the basis of the economic benefits they would gain from membership. ${ }^{7}$ It is reasonable to focus on utilitarian calculations because of the impact of the EU's Economic and Monetary Union on national economies and the daily life of EU citizens. The EU has eliminated borders, established free movement of capital, goods and services among most member states and created a common currency and a common central bank. Utilitarian theory suggests that if the benefits of these developments exceed the costs then citizens will have positive attitudes toward the EU.

Europe," Comparative Political Studies 33 (2000); Pat Lyons, "It's the Economy, Stupid: Popular Support for EU Accession in the Czech Republic," Sociologicky Casopis - Czech Sociological Review 43 (2007); Joshua A. Tucker, Alexander C. Pacek and Adam J. Berinsky, "Transitional Winners and Losers: Attitudes toward EU Membership in Post-Communist Countries," American Journal of Political Science 46 (2002).

4 Ali Çarkoğlu, "Who Wants Full Membership? Characteristics of Turkish Public Support for EU Membership," Turkish Studies 4 (2003); Çiğdem Kentmen, "Determinants of Support for EU Membership in Turkey: Islamic Attachments, Utilitarian Calculations and National Identity," European Union Politics 9 (2008).

Tucker, Pacek and Berinsky, "Transitional Winners and Losers," 558-559.

Cichowski, "Western Dreams," 149-1250.

Liesbet Hooghe and Gary Marks, "Does Identity or Economic Rationality Drive Public Opinion on European Integration?" PS: Political Science \& Politics 37 (2004): 415-416; Matthew J. Gabel, "Economic Integration and Mass Politics: Market Liberalization and Public Attitudes in the European Union," American Journal of Political Science 42 (1998): 939-941. 
The costs and/or benefits can be related either to the sociotropic national economy or to the personal pocketbook economy. Explanations regarding the national economy posit that individuals will support integration if it positively affects national economic indicators such as GDP, inflation or employment. Individuals' subjective evaluations of how the EU affects national economic conditions also shape their attitudes toward the EU: those who are satisfied with how the economy works in general are more likely to support the EU. Explanations regarding the pocketbook economy state that individual attitudes depend on how EU membership alters their personal economic conditions and opportunities: if they are content with their economic prospects, they will support EU membership. ${ }^{8}$

Models of sociotropic utilitarian calculations were successfully tested on data from Western European member states. Eichenberg and Dalton showed that inflation rate was negatively associated with support for the European Community (EC). This result implied that the impact of the EC's economic instruments, "such as VAT [Value Added Tax] financing of revenues, regulation of agricultural prices through the common agricultural policy (CAP), and especially the European Monetary System (EMS)" affected prices and consequently the economic cost-benefit analysis of individuals. ${ }^{9}$ More recent studies have focused on individuals' perceptions of the impact of the EU on national economic conditions and how this influences their opinions about the EU. For example, Karp and Bowler found that those who are not satisfied with their country's economic circumstances were against the enlargement and deepening of the EU. ${ }^{10}$

Models of the personal pocketbook economy, on the other hand, found only mixed support in the Western European context. Scholars had claimed that individuals' expectations about the economic benefits of the EU would vary with their human capital. Individuals with higher occupational skills, education and income level would have the human capital to adapt themselves to the free movement of financial capital, goods and services. Thus, they would benefit more from European integration and so would have higher support for EU membership. Gabel did find that those with the most education and skills and the highest income levels expressed more support for the EU than others in Western European member states; ${ }^{11}$ however, examining 2002 survey data from Denmark and the Netherlands, De Vreese and Boomgaarden found that occupational status did not have any significant impact on attitudes toward European integration. ${ }^{12}$ These mixed results might have been due to these studies ignoring "the redistributive, protectionist, and social-democratic commitments of the European Union". ${ }^{13}$ These commitments mean that, through the Structural and Cohesion Funds and the Common Agricultural Policy (CAP), less-developed regions and the economic sectors adversely affected by the removal of barriers receive EU support. These benefits distort the negative effects of freedom of movement on disadvantaged occupational groups,

\footnotetext{
8 Gabel, "Economic Integration," 939-941; Matthew J. Gabel and Guy D. Whitten, "Economic Conditions, Economic Perceptions, and Public Support for European Integration," Political Behavior 19 (1997): 82-85.

9 Eichenberg and Dalton, "Europeans and the European Community," 522.

10 Jeffrey A. Karp and Shaun Bowler, "Broadening and Deepening or Broadening versus Deepening: The Question of Enlargement and Europe's Hesitant Europeans," European Journal of Political Research 45 (2006): 381-386.

11 Gabel, "Economic Integration and Mass Politics," 947-948.

12 Claes H. De Vreese and Hajo G. Boomgaarden, "Projecting EU Referendums: Fear of Immigration for European Integration," European Union Politics 6 (2005): 70.

13 Piret Ehin, "Determinants of Public Support for EU Membership: Data from the Baltic Countries," European Journal of Political Research 40 (2001): 37.
} 
which in turn reduce the expected effect of human capital on attitudes toward the EU. ${ }^{14}$

The overall success of economic stimuli in explaining European attitudes within member states has led scholars to test utilitarian models in the CEECs. These studies hypothesize that post-communist CEEC citizens will also evaluate the EU by its impact on their personal financial situation and their country's economy. In particular, the membership conditions imposed on CEECs by the EU prevent any return to a planned economy. Those citizens who benefit from this transformation will be the winners of integration and thus will support EU membership. ${ }^{15}$ Scholars also emphasize that financial assistance through the EU's Structural and Cohesion Funds and interventionist social policies in the CEECs will affect individual economic cost-benefit analyses. Those who think they will gain more from accession will be more likely to support EU membership. For ten post-communist candidate countries, Tucker et al. tested whether winners of integration have positive attitudes about joining the EU. Their results revealed that winners of the transition supported EU membership, while losers opposed such membership. ${ }^{16}$

Turkey provides us with an opportunity to evaluate how individuals evaluate the economic benefits of accession to the EU in a candidate country that has neither a communist background nor a capitalist tradition akin to Western European countries. I expect citizen attitudes toward the EU to be shaped by the EU's impact on national and individual prosperity, as in Western and CEE countries. Experiences with the Customs Union, accession negotiations, economic reforms and expectations about accession should shape the individuals' cost-benefit calculations.

Turkey's economic relations with the EU started shortly after the original six members set up the European Economic Community (EEC). Turkey applied for associate partnership in 1959 and signed the related agreement with the EEC in 1963. The goal was to gradually create a customs union between Turkey and the EEC; however, the Associate Agreement did not immediately affect economic conditions in Turkey because it did not abolish tariff and non-tariff barriers as foreseen. Instead, in order to achieve large-scale industrialization, Turkey protected its domestic industry with tariffs and quotas until the $1980 \mathrm{~s} .{ }^{17}$ During the 1980s, Turkey attempted to liberalize its trade regime, yet, to accommodate the wants of their industrial and agricultural supporters, clientelist government parties failed to relinquish control over the market. Instead, successive governments provided these groups with "export incentives, tax breaks, and credits" to gain their electoral support. ${ }^{18}$

The EU's economic impact on Turkey was largely felt after 1996, when Turkey and the EU set up a customs union. As a result of the Customs Union Agreement, Turkey and the EU abolished tariff and non-tariff barriers between each other, and Turkey adopted the EU's Common External Tariff applied to third countries. The agreement also included the "harmonization of technical legislation, the abolishment of monopolies and the protection of intellectual property, [...] the mutual opening of the public procurement markets,

14 Ehin, "Determinants of Public Support," 37.

15 Thomas Christin, "Economic and Political Basis of Attitudes towards the EU in Central and East European Countries in the 1990s," European Union Politics 6 (2005): 35-36; Tucker et al., "Transitional Winners and Losers: Attitudes toward EU Membership in Post-Communist Countries," 558-559.

16 Tucker, Pacek and Berinsky, "Transitional Winners and Losers," 564-565.

17 Sübidey Togan, “Turkey: Toward EU Accession," World Economy 27 (2004): 1014

18 Mine Eder, "Implementing the Economic Criteria of EU Membership: How Difficult is it for Turkey?" Turkish Studies 4 
liberalization of trade in services, and the abolition of restrictions on the freedom of establishment". ${ }^{19}$ Scholars and decision makers expected the Customs Union to promote foreign direct investment in Turkey and provide Turkey with lower-cost access to the EU market. ${ }^{20}$

Although the economic developments of the 1980s in Turkey cannot be attributed solely to its relations with the EU, the Customs Union and the EU membership application significantly reshaped Turkey's economic structure, especially after $1995 .{ }^{21}$ Thus, Turkish citizens might also view the EU as responsible, to an extent, for the current state of the Turkish economy. Additionally, I expect that some individuals will consider themselves winners and some losers from current economic policies. Turkey's economy will continue to change as relations with the EU deepen, which I expect will also have an impact on individuals' utilitarian calculations. If people are content with the course of economic relations with the EU and economic conditions in Turkey, they will consider themselves winners in economic integration, as people did in the CEECs. In other words, I argue that the economic winners of accession to the EU will favor EU membership, both in Turkey and in the CEECs.

\section{Winners and Losers from Democratic Reforms}

The literature on support for EU membership suggests that citizens in CEECs will evaluate EU membership on the basis of the EU's effect on the consolidation of democracy in their country. Studies have suggested that if CEE citizens are satisfied with how democracy is working in their country, they will be supportive of EU membership. This is because they would think that their country will achieve democratic reforms to meet the standards of the EU. From a different point of view, those who are not satisfied with the quality and/or speed of the ongoing democratization process in their country might also support the idea of EU membership, as accession would facilitate deeper democratization. ${ }^{22}$

However, not everyone will perceive the EU's effect on the transition of the CEECs in a positive way. As Pridham puts it, "still fragile new democracies [undertook] a crippling overload of implementing change, involving [...] specific political conditions but also extensive tests of their 'ability to assume the obligations of membership"". ${ }^{23}$ Those who were concerned about the pressure of implementing new rules will neither be supportive of how democracy works in their country nor of the EU, which pressures for such changes. There may also be some individuals who want to return to communism; they will be less supportive of EU membership because it will strengthen the consolidation of democracy. Utilizing 1996 survey data from five CEECs, Chicowski showed that attitudes about the way democracy works in each CEEC were closely associated with support for integration with the EU. ${ }^{24}$

Scholars claim that the EU has also accelerated Turkey's democratization attempts. ${ }^{25}$ To satisfy membership conditions and to start accession negotiations, Turkey has passed a

19 Arjna M. Lejour and Ruud A. Mooij, “Turkish Delight: Does Turkey’s Accession to the EU Bring Economic Benefits?" Kyklos: International Review for Social Sciences 58 (2005): 91

20 Eder, "Implementing the Economic Criteria," 228

21 Togan, "Turkey," 1016-1031.

22 Cichowski, "Western Dreams, Eastern Realities," 1249-1250.

23 Geoffrey Pridham, "EU Enlargement and Consolidating Democracy in Post-Communist States: Formality and Reality," Journal of Common Market Studies 40 (2002): 954

${ }^{24}$ Cichowski, "Western Dreams, Eastern Realities," 1268-1269.

25 Aylin Güney and Petek Karateklioğlu, "Turkey's EU Candidacy and Civil-military Relations: Challenges and Prospects," Armed Forces \& Society 31 (2005): 439-462; Ziya Öniş "Domestic Politics, International Norms and Challenges to the State: TurkeyEU Relations in the Post-Helsinki Era," Turkish Studies 4 (2003): 9-34. 
series of constitutional amendments since 1995. The limitations on trade unions that prevent them from engaging in political activities were repealed (Article 52); certain categories of civil servants were given the right to form trade unions (Article 53); rules governing the formation of political parties and party membership were liberalized (Article 68) and political parties were allowed to work with organizations such as trade unions, associations, foundations and vocational institutions (Article 69). When Turkey was eventually recognized as a candidate for membership at the 1999 Helsinki Council, the EU was still urging Turkey to enhance "the right to freedom of expression", "the right to freedom of association and peaceful assembly" and "measures to reinforce the fight against torture practices", as well as to improve "opportunities for legal redress against all violations of human rights", "the functioning and efficiency of the judiciary", "the training of judges and prosecutors on European Union legislation, including in the field of human rights" and to abolish capital punishment and "provisions forbidding the use by Turkish citizens of their mother tongue in TV/radio broadcasting". ${ }^{26}$

In 2001, Turkey announced the National Program for the Adoption of the Acquis (NPAA), in which it set out the details of the further measures it will take to comply with EU membership criteria. The short-term focus was on reviewing the regulations regarding freedom of thought and expression, torture, imprisonment, duties of the police, capital punishment, freedom of association and peaceful assembly and the functioning and effectiveness of the judiciary. In that same year, the Turkish Parliament adopted 34 constitutional amendments to meet some of Turkey's accession partnership priorities. The highly criticized provision that banned publication in any language other than Turkish was removed (Article 28). Moreover, the amendments included an addition to Article 69, which removed the ambiguity surrounding the specification of activities that could allow a political party to be banned. ${ }^{27}$

I predict that the argument that winners from democratic transition will support the EU can explain not only attitudes in the CEECs, but also in those candidate countries such as Turkey that have not had a communist history yet are still in the consolidation stage of democracy. The EU has had an impact on democratic consolidation in Turkey, as outlined above, and thus, I expect Turkish individuals to view EU membership on the basis of its impact on how democracy works in their country.

\section{Data and Operationalisation of Variables}

To test the two hypotheses outlined above, I evaluate how being a winner or loser in economic and democratic transitions affects support for EU membership, and include a set of control variables in the contexts of Turkey and the CEECs. To explore these relationships, I rely on the pooled survey data from the 2002.2 and 2003.2 Candidate Countries Eurobarometers. ${ }^{28}$ The surveys involved 13 candidate countries ${ }^{29}$, but I excluded Cyprus and Malta because

26 Council of the European Union, "Council Decision of 8 March 2001 on the Principles, Priorities, Intermediate Objectives and Conditions Contained in the Accession Partnership with the Republic of Turkey," Official Journal of European Communities 235/EC (2001).

27 Turkey made several other amendments to its constitution and civil law between 2002 and 2008. However, since I tested my hypotheses using data from 2002 and 2003, I do not summarize reforms after 2002.

28 European Commission, Directorate-General Press \& Communication, Public Opinion Analysis Sector, Candidate Countries Eurobarometer 2002.2 (Ann Arbor: Inter-university Consortium for Political and Social Research, 2002); European Commission, Directorate-General Press \& Communication, Public Opinion Analysis Sector, Candidate Countries Eurobarometer 2003.2 (Ann Arbor: Inter-university Consortium for Political and Social Research, 2003).

${ }_{29}$ These are Bulgaria, Cyprus, the Czech Republic, Estonia, Hungary, Latvia, Lithuania, Malta, Poland, Romania, Slovakia, 
my study focuses on the differences between Turkey and CEECs.$^{30}$ I used the 2002.2 and 2003.2 surveys because the Eurobarometers in subsequent years did not ask respondents from CEECs how they would vote in a possible referendum; most of those countries held referendums in 2004. These two surveys included all the questions needed to operationalise my variables. In addition to the usual referendum and EU support questions, they also asked questions about satisfaction with life and democracy.

My dependent variable is individuals' support for their country's EU membership. This variable was operationalised using the Eurobarometer question asking respondents whether they would vote for their country's EU membership in a possible referendum. I coded individuals who would vote for membership as ' 1 ' and all others as ' 0 '. To increase the number of observations and to identify "firm supporters of integration", I did not delete the 'don't know' and 'would not vote' responses. ${ }^{31}$

To identify winners and losers in economic transition, I used two independent variables. The first is individuals' evaluations of the effect of EU membership on the national economy. According to my first hypothesis, those who think that their country will gain economic benefits by joining the EU will support their country's membership. In contrast, those who do not believe that the EU will help the well-being of the country will consider themselves losers in the transition; they will disapprove of their country's accession. This variable was captured through the survey question that asked "Thinking about the enlargement of the European Union to include new European countries, including [this country], do you tend to agree or tend to disagree with each of the following statements? Being a member of the European Union would help the [country's] economy". I recoded those who tended to agree as ' 1 ' and those who tended to disagree as ' 0 '.

The second variable that taps winners and losers in economic transition is self-assessment of individual economic circumstances. There are several measures of this variable, such as education and income levels. However, utilitarian and value-based approaches use education and income as independent variables. For example, Inglehart operationalised post-materialist and materialist values using education and income levels, and McLaren measured the ability of individuals to adapt to European economic integration using the same variables. ${ }^{32}$ As Ehin points out, "as both hypotheses expect these socio-economic characteristics [...] to be positively related to support for European integration, observed correlations contribute little to our ability to choose between rival theoretical perspectives". ${ }^{33}$ To overcome this problem, I determined winners and losers in the economic transitions from two survey questions in the Eurobarometers.

The first question asked respondents: "If you compare your present situation with five years ago, would you say it has improved, stayed about the same, or gotten worse?" The second question asked: "In the course of the next five years, do you expect your personal situation to improve, to stay about the same or to get worse?" For both questions, I coded those who thought that their situation had improved or would improve as ' 3 ', had stayed or

30 The pooled survey sample consists of 22, 245 individuals aged 15 and older. I used the sample weighting recommended by the Eurobarometer series.

${ }_{31}$ Piret Ehin, "Determinants of Public Support for EU Membership: Data from the Baltic Countries," European Journal of Political Research 40 (2001): 43.

32 Ronald Inglehart, Culture Shift in Advanced Industrial Society (Princeton: Princeton University Press, 1990); Lauren M. McLaren, "Public Support for the European Union: Cost/Benefit Analysis or Perceived Cultural Threat?" The Journal of Politics 64 (2002): 560 .

33 Ehin, "Determinants of Public Support," 36 
would stay about the same as ' 2 ' and had gotten or would get worse as ' 1 '. I averaged the responses to these two survey questions to create a measure of individuals' evaluation of their economic circumstances. Tucker et al. used a similar self-assessment measure, although their survey questions asked respondents about their financial situation rather than personal situation. The Candidate Country Eurobarometers that I utilize in this analysis did not ask the same financial questions. Tucker et al. suggested that demographic characteristics can also be used as measures of winners and losers $;{ }^{34}$ however, because the definition of winner and loser varies according to individual perception, it is more reliable to use self-evaluation questions as measures of winner and loser status.

Individuals' evaluations of their country's democratic system are also expected to affect attitudes toward the EU. Those who are satisfied with how democracy works in their country will view themselves as winners in accession. They will seek EU membership to preserve the changes and to achieve even more democratic reforms. Those who are not satisfied with the transition will consider themselves losers and blame the EU for their circumstances. Consequently, to avoid more changes to the system, they will not support their country's EU membership application. I used the Eurobarometer question that asked respondents whether they were satisfied with how democracy works in their country. The answers ranged from 1 "not at all satisfied" to 4 "very satisfied". I coded "don't know" answers as missing data.

Alongside the measures of winners and losers in economic and democratic transitions, I included variables for national identity, religiosity, knowledge about the EU, gender, age, education, income and year of the survey as controls. I do not make any predictions about the direction of these coefficients. The first control variable is national identity and I operationalised it using two survey questions. The first question asked respondents: "In the near future do you see yourself as 1 [nationality] only, 2 [nationality] and European, 3 European and [nationality], 4 European only?". To differentiate individuals with a strong sense of nationality from all others, I coded those who indicated only their own nationality as ' 1 ', and all others as ' 0 '. I then multiplied their answers to that question with their responses to the following question: "Would you say you are very proud, fairly proud, not very proud, or not at all proud to be [nationality - indicate citizenship]?". The responses for this question ranged from 1 "not at all proud" to 4 "very proud".

The second control variable is religiosity. The surveys asked respondents "Do you attend religious services other than weddings or funerals several times a week, once a week, a few times a year, once a year or less, or never?" The responses ranged from 5 "several times a week" to 1 "never". The third control variable is knowledge about the EU. Respondents were asked to evaluate their knowledge about the EU, its institutions and its policies using a scale from 1 to 10 , with 1 representing "know nothing at all" and 10 "know a great deal". The fourth control variable is gender, with women coded as ' 1 ' and men coded as ' 0 '. The fifth control is age, which documents the age of the respondent at the time of the survey. The sixth control variable is income. I created four binary variables for the four income levels reported in the Eurobarometers. I coded those whose income level was between 1 and 3 as 'low-income respondents', those whose income level was between 4 and 5 as 'low-tomid income respondents', those whose income level was between 6 and 7 as 'mid-to-high 
income respondents' and those whose income level was between 8 and 10 as 'high-income respondents'. The high-income variable formed the base category. The seventh control variable is education, which represents the age of the respondent when she or he stopped full-time education. The last control variable is the year of the survey, to control for the effect of time. It is a binary variable, with 2002 coded as ' 1 ', and 2003 coded as ' 0 '.

\section{Estimation Procedure and Results}

Because of the binary dependent variable, I used logit regression techniques to estimate the models, along with robust standard errors. I report the results in Table 1, which shows that the models performed reasonably well. The explanatory powers of the models, as measured by Proportional Reduction in Error (PRE), are generally high. For example, the models explain 58 percent of the variation in individual support in the Czech Republic, 50 percent in Estonia and 45 percent in Poland. The performance of the model is also relatively high in Turkey. The independent variables explain almost 38 percent of the variation in support for EU membership in Turkey. The lowest PRE is for Romania, at about eight percent. All the models yield statistically significant chi-squares, which means that the models fit the data. Multicollinearity was not a problem in estimating these models, because the highest Variance Inflation Factor (VIF) was below two, which is the generally accepted criterion for multicollinearity. ${ }^{35}$

Table 1 reveals that individual support for EU membership reacts to similar factors in Turkey as in the CEECs. As the economic winners and losers argument predicts, citizens living in Turkey and in post-communist member states assess their country's EU membership on the basis of its economic benefits to the country and their own situation. Table 1 shows that those who think their country's economic circumstances will improve with EU membership are more likely to vote for accession in a possible referendum, as are those who are satisfied with their personal situation. Those individuals perceive themselves as the winners from integration and thus support deeper and permanent ties with the EU.

35 To test the robustness of my findings, I also used different coding methods for my dependent variable. I recoded those respondents who would support membership as ' 1 ' and those who would not as ' 0 '. I deleted the 'don't know' and 'would not vote' responses. I also ran separate models with alternative control variables of religious attachment, occupation, education level and EU knowledge. In these cases, the coefficient estimates for the key independent variables retained their significance and direction. These results are available upon request. 
Table 1 - Logit Results for Support for EU Membership in Turkey and the CEECs

\begin{tabular}{|c|c|c|c|c|c|c|c|c|c|c|c|}
\hline & Turkey & Bulgaria & $\begin{array}{c}\text { Czech } \\
\text { Republic }\end{array}$ & Estonia & Hungary & Latvia & Lithuania & Poland & Romania & Slovakia & Slovenia \\
\hline Predictors & \multicolumn{11}{|c|}{$\begin{array}{c}\text { Coefficient } \\
\text { (Robust Standard Error) }\end{array}$} \\
\hline Intercept & $\begin{array}{c}-3.542^{* * * *} \\
(.694)\end{array}$ & $\begin{array}{c}*-3.883 * * * \\
(.86)\end{array}$ & $\begin{array}{c}* 6.517 * * * \\
(1.058)\end{array}$ & $\begin{array}{c}-5.569 * * * \\
(.724)\end{array}$ & $\begin{array}{c}-4.969 * * * \\
(.89)\end{array}$ & $\begin{array}{l}-5.551 * * * \\
\quad(.749)\end{array}$ & $\begin{array}{l}-4.596 * * * \\
\quad(.864)\end{array}$ & $\begin{array}{l}-4.882 * * * \\
\quad(1.522)\end{array}$ & $\begin{array}{c}-.414 \\
(1.049)\end{array}$ & $\begin{array}{l}-4.513 * * * \\
\quad(.918)\end{array}$ & $\begin{array}{c}-5.328 * * * \\
(.887)\end{array}$ \\
\hline $\begin{array}{l}\text { National } \\
\text { economic } \\
\text { prospects }\end{array}$ & $\begin{array}{l}2.986 * * * \\
(.211)\end{array}$ & $\begin{array}{l}2.641 * * * \\
\quad(.24)\end{array}$ & $\begin{array}{l}2.701 * * * \\
\quad(.209)\end{array}$ & $\begin{array}{c}1.887 * * * \\
(.185)\end{array}$ & $\begin{array}{l}2.447 * * * \\
(.204)\end{array}$ & $\begin{array}{l}2.611 * * * \\
(.194)\end{array}$ & $\begin{array}{c}2.576^{* * *} \\
(.215)\end{array}$ & $\begin{array}{c}2.539 * * * \\
(.226)\end{array}$ & $\begin{array}{l}2.035 * * * \\
\quad(.35)\end{array}$ & $\begin{array}{l}2.716^{* * * *} \\
(.232)\end{array}$ & $\begin{array}{c}1.842 * * * \\
(.192)\end{array}$ \\
\hline $\begin{array}{l}\text { Personal } \\
\text { situation }\end{array}$ & $\begin{array}{l}.339 * * \\
(.126)\end{array}$ & $\begin{array}{l}.641 * * \\
(.236)\end{array}$ & $\begin{array}{l}.52 * * \\
(.199)\end{array}$ & $\begin{array}{l}.47 * * * \\
(.128)\end{array}$ & $\begin{array}{l}.93 * * * \\
(.165)\end{array}$ & $\begin{array}{l}.618 * * * \\
(.168)\end{array}$ & $\begin{array}{l}.545^{* *} \\
(.178)\end{array}$ & $\begin{array}{c}.804 * * * \\
(.165)\end{array}$ & $\begin{array}{l}.517 * \\
(.253)\end{array}$ & $\begin{array}{c}.35^{*} \\
(.172)\end{array}$ & $\begin{array}{l}.494 * * \\
(.165)\end{array}$ \\
\hline $\begin{array}{l}\text { Satisfaction } \\
\text { with } \\
\text { democracy }\end{array}$ & $\begin{array}{c}.233 \\
(.139)\end{array}$ & $\begin{array}{l}.585^{* *} \\
(.187)\end{array}$ & $\begin{array}{c}.614 * * * \\
(.148)\end{array}$ & $\begin{array}{c}.369 * * * \\
(.109)\end{array}$ & $\begin{array}{l}.183 \\
(.13)\end{array}$ & $\begin{array}{l}.386^{* *} \\
(.126)\end{array}$ & $\begin{array}{c}.449 * * * \\
(.138)\end{array}$ & $\begin{array}{l}-.033 \\
(.132)\end{array}$ & $\begin{array}{c}.17 \\
(.232)\end{array}$ & $\begin{array}{l}.52 * * * \\
(.162)\end{array}$ & $\begin{array}{c}.632 * * * \\
(.132)\end{array}$ \\
\hline $\begin{array}{l}\text { National } \\
\text { identity }\end{array}$ & $\begin{array}{c}-.28 * * * \\
(.052)\end{array}$ & $\begin{array}{c}-.218^{* * *} \\
(.067)\end{array}$ & $\begin{array}{c}-.267 * * * \\
\quad .069)\end{array}$ & $\begin{array}{c}-.199 * * * \\
(.054)\end{array}$ & $\begin{array}{c}-.137 * * \\
(.051)\end{array}$ & $\begin{array}{c}-.177 * * * \\
(.055)\end{array}$ & $\begin{array}{l}-.046 \\
(.069)\end{array}$ & $\begin{array}{c}-.299 * * * \\
(.056)\end{array}$ & $\begin{array}{c}-.064 \\
(.071)\end{array}$ & $\begin{array}{c}-.254 * * * \\
(.064)\end{array}$ & $\begin{array}{c}-.208 * * * \\
(.053)\end{array}$ \\
\hline Religiosity & $\begin{array}{l}-.087 \\
(.087)\end{array}$ & $\begin{array}{c}.086 \\
(.113)\end{array}$ & $\begin{array}{l}-.092 \\
(.097)\end{array}$ & $\begin{array}{l}-.004 \\
(.097)\end{array}$ & $\begin{array}{c}-.061 \\
(.086)\end{array}$ & $\begin{array}{l}-.143 \\
(.105)\end{array}$ & $\begin{array}{l}.214^{*} \\
(.108)\end{array}$ & $\begin{array}{l}-.176 \\
(.119)\end{array}$ & $\begin{array}{l}-.121 \\
(.146)\end{array}$ & $\begin{array}{l}-.135 \\
(.079)\end{array}$ & $\begin{array}{l}.058 \\
(.08)\end{array}$ \\
\hline $\begin{array}{l}\text { Knowledge } \\
\text { about the } \\
\text { EU }\end{array}$ & $\begin{array}{c}.318 * * * \\
(.057)\end{array}$ & $\begin{array}{c}.504 * * * \\
(.104)\end{array}$ & $\begin{array}{c}.334 * * * \\
(.078)\end{array}$ & $\begin{array}{c}.336 * * * \\
(.059)\end{array}$ & $\begin{array}{c}.291 * * * \\
(.069)\end{array}$ & $\begin{array}{c}.383 * * * \\
(.064)\end{array}$ & $\begin{array}{c}.325 * * * \\
(.073)\end{array}$ & $\begin{array}{c}.465 * * * \\
(.088)\end{array}$ & $\begin{array}{c}.364 * * * \\
(.109)\end{array}$ & $\begin{array}{c}.308 * * * \\
(.07)\end{array}$ & $\begin{array}{c}.436 * * * \\
(.088)\end{array}$ \\
\hline Gender & $\begin{array}{c}.075 \\
(.198)\end{array}$ & $\begin{array}{c}-.052 \\
(.236)\end{array}$ & $\begin{array}{c}.08 \\
(.21)\end{array}$ & $\begin{array}{c}.021 \\
(.152)\end{array}$ & $\begin{array}{l}-.152 \\
(.191)\end{array}$ & $\begin{array}{c}-.174 \\
(.189)\end{array}$ & $\begin{array}{c}.101 \\
(.208)\end{array}$ & $\begin{array}{c}-.25 \\
(.199)\end{array}$ & $\begin{array}{l}-.506 \\
(.284)\end{array}$ & $\begin{array}{l}-.249 \\
(.21)\end{array}$ & $\begin{array}{l}.047 \\
(.2)\end{array}$ \\
\hline Age & $\begin{array}{l}.02 * * \\
(.007)\end{array}$ & $\begin{array}{c}-.008 \\
(.007)\end{array}$ & $\begin{array}{c}.001 \\
(.007)\end{array}$ & $\begin{array}{c}.006 \\
(.005)\end{array}$ & $\begin{array}{c}.023 * * * \\
(.006)\end{array}$ & $\begin{array}{l}.011 * \\
(.006)\end{array}$ & $\begin{array}{c}.007 \\
(.007)\end{array}$ & $\begin{array}{l}.016^{*} \\
(.007)\end{array}$ & $\begin{array}{l}.002 \\
(.008)\end{array}$ & $\begin{array}{l}.014^{*} \\
(.007)\end{array}$ & $\begin{array}{c}.021 * * * \\
(.006)\end{array}$ \\
\hline Education & $\begin{array}{l}.001 \\
(.006)\end{array}$ & $\begin{array}{c}.011 \\
(.021)\end{array}$ & $\begin{array}{l}.104^{*} \\
(.046)\end{array}$ & $\begin{array}{c}.044 \\
(.023)\end{array}$ & $\begin{array}{c}.017 \\
(.027)\end{array}$ & $\begin{array}{l}.027 \\
(.02)\end{array}$ & $\begin{array}{c}.004 \\
(.011)\end{array}$ & $\begin{array}{c}.081 \\
(.058)\end{array}$ & $\begin{array}{l}-.014 \\
(.017)\end{array}$ & $\begin{array}{c}.06 \\
(.034)\end{array}$ & $\begin{array}{l}.004 \\
(.02)\end{array}$ \\
\hline Low income & $\begin{array}{l}.651 * \\
(.294)\end{array}$ & $\begin{array}{l}-.012 \\
(.291)\end{array}$ & $\begin{array}{l}-.342 \\
(.316)\end{array}$ & $\begin{array}{c}-.22 \\
(.223)\end{array}$ & $\begin{array}{c}-.35 \\
(.254)\end{array}$ & $\begin{array}{c}.065 \\
(.244)\end{array}$ & $\begin{array}{l}-.036 \\
(.274)\end{array}$ & $\begin{array}{l}-.104 \\
(.228)\end{array}$ & $\begin{array}{c}.062 \\
(.382)\end{array}$ & $\begin{array}{c}-.28 \\
(.254)\end{array}$ & $\begin{array}{l}-.291 \\
(.249)\end{array}$ \\
\hline $\begin{array}{l}\text { Low-mid } \\
\text { Income }\end{array}$ & $\begin{array}{l}.505 \\
(.286)\end{array}$ & $\begin{array}{c}.363 \\
(.327)\end{array}$ & $\begin{array}{c}.07 \\
(.272)\end{array}$ & $\begin{array}{l}-.124 \\
(.207)\end{array}$ & $\begin{array}{l}-.086 \\
(.269)\end{array}$ & $\begin{array}{l}.061 \\
(.259)\end{array}$ & $\begin{array}{c}.15 \\
(.304)\end{array}$ & $\begin{array}{l}-.640^{*} \\
(.282)\end{array}$ & $\begin{array}{l}-.219 \\
(.409)\end{array}$ & $\begin{array}{c}.405 \\
(.307)\end{array}$ & $\begin{array}{l}.678^{* *} \\
(.276)\end{array}$ \\
\hline $\begin{array}{l}\text { Mid-high } \\
\text { income }\end{array}$ & $\begin{array}{c}.21 \\
(.307)\end{array}$ & $\begin{array}{l}.743^{*} \\
(.366)\end{array}$ & $\begin{array}{c}.034 \\
(.306)\end{array}$ & $\begin{array}{l}.235 \\
(.208)\end{array}$ & $\begin{array}{l}.009 \\
(.265)\end{array}$ & $\begin{array}{l}-.336 \\
(.272)\end{array}$ & $\begin{array}{l}-.362 \\
(.296)\end{array}$ & $\begin{array}{l}-.531 \\
(.315)\end{array}$ & $\begin{array}{l}-.024 \\
(.406)\end{array}$ & $\begin{array}{l}.447 \\
(.37)\end{array}$ & $\begin{array}{c}.034 \\
(.293)\end{array}$ \\
\hline Year & $\begin{array}{l}.178 \\
(.212)\end{array}$ & $\begin{array}{l}-.042 \\
(.231)\end{array}$ & $\begin{array}{l}.101 \\
(.219)\end{array}$ & $\begin{array}{l}.286 \\
(.161)\end{array}$ & $\begin{array}{c}.649 * * * \\
(.199)\end{array}$ & $\begin{array}{l}.455^{*} \\
(.206)\end{array}$ & $\begin{array}{c}-.613 * * \\
(.206)\end{array}$ & $\begin{array}{l}.291 \\
(.254)\end{array}$ & $\begin{array}{l}-.284 \\
(.278)\end{array}$ & $\begin{array}{l}.359 \\
(.231)\end{array}$ & $\begin{array}{c}.128 \\
(.232)\end{array}$ \\
\hline Pseudo $\mathrm{R}^{2}$ & .3659 & .4161 & .4619 & .2596 & .3034 & .3651 & .3821 & .3881 & .1813 & .3672 & .3247 \\
\hline $\begin{array}{l}\text { Log } \\
\text { Likelihood }\end{array}$ & -472.543 & -360.395 & -416.446 & -665.114 & -546.483 & -493.859 & -415.801 & -474.324 & -292.093 & -499.007 & -493.924 \\
\hline $\mathrm{N}$ & 1406 & 1378 & 1192 & 1296 & 1472 & 1139 & 1182 & 1345 & 1375 & 1501 & 1332 \\
\hline PRE (\%) & 37.82 & 37.55 & 57.57 & 50.40 & 32.29 & 53.99 & 44.04 & 45.38 & 7.69 & 38.82 & 35.08 \\
\hline
\end{tabular}

Note 1: I used STATA 9.2 in this research.

Note 2: * Significant at .05 level; ** significant at .01 level; *** significant at .001 level in two-tailed tests of significance. 
Table 2 shows the magnitude of the impact that the statistically significant variables had on the dependent variable. The cell entries show the discrete change in the probability of support for one unit change in each independent variable by changing the independent variables from a half standard deviation below the mean to a half standard deviation above the mean while holding other variables constant. For the dichotomous independent variables, it is the change in the probability of support for a discrete change in the independent variables from 0 to $1 .{ }^{36}$ Regarding the national economy, the results reveal that a Turkish citizen who thinks that the EU will contribute to the national economy is 56 percentage points more likely to vote for EU membership than a citizen who thinks otherwise. Similarly, in Latvia, if a citizen believes the national economy will benefit from being a member of the EU, the probability of him or her voting for EU membership increases almost 58 percentage points. The change is also above 50 percentage points in the Czech Republic, Poland and Slovakia. In the other countries, the effect of the national economic prospect variable on the probability of support is lower but not less than 20 percent.

\begin{tabular}{|c|c|c|c|c|c|c|c|c|c|c|c|}
\hline & Turkey & Bulgaria & $\begin{array}{l}\text { Czech } \\
\text { Republic }\end{array}$ & Estonia & Hungary & Latvia & Lithuania & Poland & Romania & Slovakia & Slovenia \\
\hline Predictors & \multicolumn{11}{|c|}{$\begin{array}{c}\text { Coefficient } \\
\text { (Robust Standard Error) }\end{array}$} \\
\hline $\begin{array}{l}\text { National } \\
\text { economic } \\
\text { prospects }\end{array}$ & .562 & .38 & .563 & .426 & .455 & .574 & .481 & .503 & .202 & .508 & .312 \\
\hline $\begin{array}{l}\text { Personal } \\
\text { situation }\end{array}$ & .03 & .027 & .062 & .077 & .072 & .094 & .049 & .074 & .015 & .028 & .039 \\
\hline $\begin{array}{l}\text { Satisfaction } \\
\text { with } \\
\text { democracy }\end{array}$ & - & .032 & .088 & .069 & - & .074 & .049 & - & - & .045 & .06 \\
\hline $\begin{array}{l}\text { National } \\
\text { identity }\end{array}$ & -.063 & -.025 & -.079 & -.07 & -.031 & -.067 & -.009 & -.07 & - & -.043 & -.047 \\
\hline Religiosity & - & - & - & - & - & - & .027 & - & - & - & - \\
\hline $\begin{array}{l}\text { Knowledge } \\
\text { of European } \\
\text { Union }\end{array}$ & .069 & .063 & .12 & .137 & .059 & .159 & .081 & .115 & .029 & .067 & .106 \\
\hline Gender & - & - & - & - & - & - & - & - & - & - & - \\
\hline Age & .034 & - & - & - & .052 & .049 & - & .04 & - & .027 & .049 \\
\hline Education & - & - & .064 & - & - & - & - & - & - & - & - \\
\hline Low income & .033 & - & - & - & - & - & - & - & - & - & - \\
\hline $\begin{array}{l}\text { Low-mid } \\
\text { income }\end{array}$ & - & - & - & - & - & - & - & -.03 & - & - & .036 \\
\hline $\begin{array}{l}\text { Mid-high } \\
\text { income }\end{array}$ & - & .02 & - & - & - & - & - & - & - & - & - \\
\hline Year & - & - & - & - & .08 & .109 & -.083 & - & - & - & - \\
\hline
\end{tabular}

Note: The probability changes are not listed for statistically insignificant variables.

${ }_{36}$ Scott J. Long, Regression Models for Categorical and Limited Dependent Variables (Thousand Oaks, CA: Sage Publications, 1997). 
Regarding personal situations, a standard deviation increase in a Turkish individual's situation perception translates into only a three percent increase in her or his probability of supporting Turkey's EU accession. In Latvia, personal situation has a larger impact on individual attitudes toward the EU: changing the personal situation variable from one to zero results in an increase of almost ten percent in the probability of EU support. The impact of this variable on the dependent variable is lowest in Romania: changing the personal situation variable from one to zero results in only a two percentage point increase in the probability of EU support.

The performance of the democratic satisfaction variable offers weaker support for the winners and losers in democratic transitions hypothesis. In Turkey, Hungary, Poland and Romania, the satisfaction with democracy variable has a statistically insignificant effect on EU support. This result suggests that the probability that an individual will support EU accession is not associated with his or her assessment of how democracy works in their country. By contrast, in Bulgaria, the Czech Republic, Estonia, Latvia, Lithuania, Slovakia and Slovenia, citizens apparently recognise a link between democratic transition, regime performance and EU membership: a one standard deviation increase in satisfaction with democracy leads to at least a three percent increase in the probability of support in these countries. It is also interesting to see that the coefficient of the satisfaction variable is not negative in any of the countries. If the variable had a significant effect then it would indicate that those who are not satisfied with democracy would be more likely to support EU membership. This might imply that citizens do not see a link between the changes in their country's regime and its attempt to meet EU membership conditions.

Turning to the control variables, in all countries except Lithuania and Romania, the effect of attachment to national identity on individual attitudes toward EU membership is significant and negative. Knowledge about the EU also has a significant effect on support in all countries. Religiosity does not have a statistically significant effect in any of the candidate countries, with the exception of Lithuania. Gender does not have a statistically significant impact in any country. Education has a statistically significant (and positive) impact on opinion only in the Czech Republic: there, people with higher education are more likely to support membership to the EU. In Turkey, Hungary, Latvia, Poland, Slovakia and Slovenia, older people are more likely to support their country's accession to the EU. The effect of being in a low-income group on support for the EU is significant merely in Turkey. Low-mid and mid-high income groups are significant in several CEECs, but not in Turkey. Lastly, in Hungary and Latvia, citizens were more likely to vote for EU membership, but less likely to vote for the EU in Lithuania in 2002 than in 2003.

\section{Discussion and Conclusion}

In this study, I compared the determinants of support for EU membership in Turkey and the former communist candidate countries in Central and Eastern Europe. The aim was to understand whether theories formerly developed for the CEECs could be generalized and applied to a country, like Turkey, lacking a similar communist background to the CEECs. More specifically, I examined whether, in all countries studied, those who are satisfied with the political and economic changes in their country support EU membership. The logit regression results revealed that those who benefited, or thought they would benefit in the future, were more likely to support their country's accession to the EU. However, the results also revealed that satisfaction with how democracy works did not have a significant impact on individual support for EU membership. 
Nevertheless, the results of this analysis imply that it is not merely citizens of postcommunist CEECs who might feel like winners and losers as a result of economic changes. Turkey might not be going through a similar transition process from communism to democracy and market economy; however, its citizens still think that relations with the EU have affected the course of economic developments in Turkey. The Turkish economy has become more transparent, competitive and open. Citizens' evaluations of the EU's contribution to these changes to the Turkish economy, and their perception of their own economic circumstances, are associated with how they view Turkey's EU membership. In contrast, attitudes toward democratic transition do not affect how Turkish, Hungarian, Polish and Romanian citizens view the EU. This result might be because the effect of EU conditionality has been challenged by other domestic factors in these countries. For example, Schimmelfennig et al. argued that "the weakness of society vis-à-vis the state" has limited the influence of civil society organizations supportive of EU membership and instead has given "governments and parties ample space for discretionary decision-making". ${ }^{37}$

This study also expanded understanding of how opinion about the EU is formed in Turkey. In contrast to the proliferation of research on why Turkey has so far failed to become a member of the EU and what Turkish elites think about EU accession, there is limited empirical research on Turkish public opinion about the EU. The existing studies do not provide a comparison of Turkish public attitudes with other candidate or member state citizens. This study is the first to investigate Turkish public opinion from a comparative perspective. Future studies might focus on how aggregate factors such as the strength of society vis-à-vis the state mediate the impact of attitudes toward democratic transition on support for EU membership. Moreover, research on the determinants of support for EU accession is needed in recent candidate countries, including Croatia, the Former Yugoslav Republic of Macedonia, Iceland, Montenegro and Serbia.

\section{Bibliography}

Brinegar, Adam P., and Seth K. Jolly. "Location, location, location: National Contextual Factors and Public Support for European Integration.” European Union Politics 6 (2005): 155-180.

Çarkoğlu, Ali. "Who Wants Full Membership? Characteristics of Turkish Public Support for EU Membership." Turkish Studies 4 (2003): 171-194.

Christin, Thomas. "Economic and Political Basis of Attitudes towards the EU in Central and East European Countries in the 1990s." European Union Politics 6 (2005): 29-57.

Cichowski, Rachel A. "Western Dreams, Eastern Realities: Support for the European Union in Central and Eastern Europe." Comparative Political Studies 33 (2000): 1243-1278.

Council of the European Union. "Council Decision of 8 March 2001 on the Principles, Priorities, Intermediate Objectives and Conditions Contained in the Accession Partnership with the Republic of Turkey." Official Journal of European Communities 2001/235/EC (2001).

De Vreese, Claes H., and Hajo G. Boomgaarden. "Projecting EU Referendums: Fear of Immigration for European Integration." European Union Politics 6 (2005): 59-82.

Eder, Mine. "Implementing the Economic Criteria of EU Membership: How Difficult is it for Turkey?" Turkish Studies 4 (2003): 219-244.

Ehin, Piret. "Determinants of Public Support for EU Membership: Data from the Baltic Countries." European

37 Frank Schimmelfennig, "Strategic Calculation and International Socialization: Membership Incentives, Party Constellations, and Sustained Compliance in Central and Eastern Europe," International Organization 59 (2005): 498. 
Journal of Political Research 40 (2001): 31-56.

Eichenberg, Richard, and Russell J. Dalton. "Europeans and the European Community: The Dynamics of Public Support for European Integration.” International Organization, 47 (1993): 507-534.

European Commission, Directorate-General Press \& Communication, Public Opinion Analysis Sector. Candidate Countries Eurobarometer 2002.2. Ann Arbor: Inter-university Consortium for Political and Social Research, 2002.

European Commission, Directorate-General Press \& Communication, Public Opinion Analysis Sector. Candidate Countries Eurobarometer 2003.2. Ann Arbor: Inter-university Consortium for Political and Social Research, 2003.

Franklin, Mark, Michael Marsh, and Lauren McLaren. "Uncorking the Bottle? Popular Opposition to European Unification in the Wake of the Maastricht Treaty." Journal of Common Market Studies, 32 (1994) :455-472.

Gabel, Matthew J., and Guy Whitten. "Economic Conditions, Economic Perceptions, and Public Support for European Integration.” Political Behavior 19 (1997): 81- 96.

Gabel, Matthew J. "Public Support for European Integration: An Empirical Test of Five Theories." Journal of Politics 60 (1998): 333-354.

Güney, Aylin, and Petek Karateklioğlu. “Turkey's EU Candidacy and Civil-military Relations: Challenges and Prospects.” Armed Forces \& Society 31 (2005): 439-462.

Hooghe, Liesbet, and Gary Marks. "Does Identity or Economic Rationality Drive Public Opinion on European Integration?” PS: Political Science \& Politics 37 (2004): 415-420.

Inglehart, Ronald. Culture Shift in Advanced Industrial Society. Princeton: Princeton University Press, 1990.

Karp, Jeffrey A., and Shaun Bowler. "Broadening and Deepening or Broadening versus Deepening: The Question of Enlargement and Europe's Hesitant Europeans.” European Journal of Political Research 45 (2006): 369-390.

Kentmen, Çiğdem. "Determinants of Support for EU Membership in Turkey: Islamic Attachments, Utilitarian Calculations and National Identity." European Union Politics 9 (2008): 487-510.

Lejour, Arjna M., and Ruud A. Mooij. “Turkish Delight: Does Turkey’s Accession to the EU Bring Economic Benefits?” Kyklos:International Review for Social Sciences 58 (2005): 87-121.Long, Scott J. Regression Models for Categorical and Limited Dependent Variables. Thousand Oaks, CA: Sage Publications, 1997.

Lyons, Pat. "It's the Economy, Stupid: Popular Support for EU Accession in the Czech Republic." Sociologicky Casopis - Czech Sociological Review 43 (2007): 523-60.

McLaren, Lauran M. "Public Support for the European Union: Cost/Benefit Analysis or Perceived Cultural Threat?" The Journal of Politics 64 (2002): 551-566.

Öniş, Ziya. "Domestic Politics, International Norms and Challenges to the State: Turkey-EU Relations in the PostHelsinki Era.” Turkish Studies 4 (2003): 9-34.

Pridham, Geoffrey. "EU Enlargement and Consolidating Democracy in Post-Communist States: Formality and Reality." Journal of Common Market Studies 40 (2002): 953-973.

Schimmelfennig, Frank. "Strategic Calculation and International Socialization: Membership Incentives, Party Constellations, and Sustained Compliance in Central and Eastern Europe." International Organization 59 (2005): 498.

Togan, Sübidey. “Turkey: Toward EU Accession.” World Economy 27 (2004): 1013-1045.

Tucker, Joshua A., Alexander C. Pacek, and Adam J. Berinsky. "Transitional Winners and Losers: Attitudes toward EU Membership in Post-Communist Countries.” American Journal of Political Science 46 (2002): 557-571. 